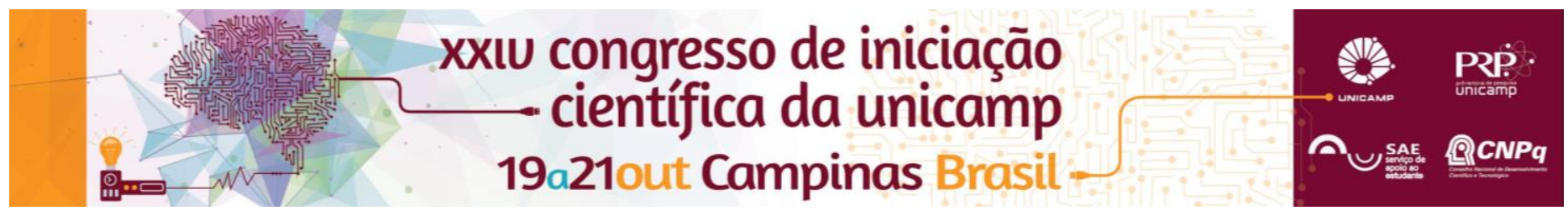

\title{
A Educação de Jovens e Adultos em Campinas - SP: um estudo da situação dos egressos dos anos iniciais do Ensino Fundamental
}

\section{Liliane Esteve Ramalho*, Sandra Fernandes Leite}

\begin{abstract}
Resumo
Esta pesquisa tem como objetivo realizar um estudo sobre a situação dos egressos da modalidade EJA matrículados nos anos iniciais do Ensino Fundamental do município de Campinas - SP, com o objetivo de traçar a situação desse público e buscar identificar os impactos da EJA em suas vidas pessoais e profissionais, a continuidade (ou descontinuidade) de seus estudos. Nessa comunicação é descrita a primeira etapa dessa pesquisa: a realização da pesquisa bibligráfica e documental caracterizando a oferta da modalidade EJA no município, do levamento das escolas e a elaboração do questionário para os egressos. São apresentadas algumas análises preliminares dos dados levantados e são indicadas as atividades de continuidade da pesquisa na segunda etapa.
\end{abstract}

\section{Palavras-chave:}

Educação de Jovens e Adultos, perfil, egressos.

\section{Introdução}

A Educação de Adultos e atualmente a modalidade Educação de Jovens e Adultos (EJA) permeiam a história da educação no Brasil. Elas seguem os ritmos da história da sociedade em seus modelos econômicos, políticos e sociais, ditados pelas relações de poder de grupos ideologicamente dominantes (LEITE,2013). E no contexto de dificuldades de consolidar 0 direito à terminalidade da EJA e os caminhos que os alunos têm que seguir para ter 0 direito a uma aprendizagem ao longo da vida. A proposta dessa pesquisa é a realização de um estudo pelo qual se identificará a situação dos egressos da EJA no município de Campinas-SP e buscará identificar os impactos da EJA em suas vidas pessoais e profissionais, a continuidade (ou descontinuidade) de seus estudos. O objetivo é realizar um estudo sobre as possibilidades de continuidade dos estudos dos egressos da modalidade EJA matrículados nos anos iniciais do Ensino Fundamental. Propõe-se a identificação dos egressos com uma pré-análise de entrada e saída por períodos de matrícula. Esta pesquisa está dividida em duas etapas. Uma de levantamento bibliográfico e, de dados, seleção de escolas e de criação do questionário. Uma outra de coleta, análise e discussão dos dados para mapear a situação dos egressos.

\section{Resultados e Discussão}

$\mathrm{Na}$ primeira etapa desse trabalho foi realizada uma pesquisa bibliografica sobre a EJA no munícipio de Campinas - SP e uma pesquisa documental realizadas nos documentos legais tais como as legislações, diretrizes, resoluções e portarias do município voltados para a modalidade EJA nos anos iniciais do Ensino Fundamental. Foi realizado um levantamento das escolas de Campinas onde serão selecionados os egressos. A amostra foi constituída a partir do levantamento das escolas que oferecem a modalidade EJA na rede pública municipal de Campinas/SP. A elaboração do questionário passou pela consulta a trabalhos acadêmicos e artigos que trataram da questão dos egressos e buscou montar uma base de perguntas que capturassem a questão da continuidade dos estudos.

\section{Conclusões}

A EJA em Campinas deve ser compreendida a partir de seus contextos históricos, políticos, econômicos, sociais e culturais e de seus marcos legais e educacionais vigentes na esfera federal com repercussão no município de Campinas (CAMPINAS, 2015). Em Campinas, de acordo com o INEP (2014), existiam 8.308 matrículas em 2013. Assumindo um número de concluintes na ordem de 2.000 , propõe-se uma amostra de $10 \%$ para o levantamento de egressos junto às escolas de Campinas que oferecem a EJA, algo na ordem de 200 questionários. Para o estudo de caso em Campinas, o universo foi composto de uma amostra dos egressos que estudaram nos últimos cinco anos na EJA, uma janela de tempo sugerida entre 2010 e 2015. A análise dos dados obtidos indica que o município de Campinas tem uma política de oferta para a modalidade EJA bastante diversificada e com linhas de atuação que vão das salas de alfabetização até a possibilidade de formação profissional

$\mathrm{Na}$ segunda etapa da pesquisa será aplicado este questionário para os egressos. Esta pesquisa tem por desafio conhecer mais profundamente as transformações que estão ocorrendo nos perfis dos egressos da modalidade EJA, de modo a possibilitar condições de refletir sobre o que está sendo proposto para a modalidade e o que efetivamente está ocorrendo. O que cabe buscar é se esse leque de possibilidades realmente atende ao egresso da EJA.

\section{Agradecimentos}

Agradecemos o apoio do Serviço de Apoio ao Estudante (SAE) da Unicamp pela concessão da bolsa BAS e à FAEPEX/Unicamp pelo apoio através do Programa Auxílio Início de Carreira de Docentes da Unicamp.

INEP. Sinopses Estatísticas da Educação Básica. 2014. Disponível em: http://portal.inep.gov.br/basica-censo-escolar-sinopse-sinopse . Acesso em 20/03/2014.

LEITE, Sandra. Fernandes. O direito à Educação Básica para jovens e adultos na modalidade EJA no Brasil: um resgaste histórico e legal. Curitiba: CRV 2013. 324p.

Documento-Base Plano Municipal de Educação. Secretaria

Municipal de Educação. Campinas. 64p. 2015. Disponível em: http://www.campinas.sp.gov.br/governo/educacao/plano-municipal-educacao2014-2015/arquivos/doc base.pdf. Acesso em: 16. Jun. 2016. 